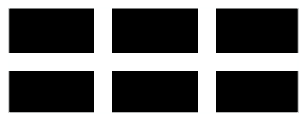

ThE WiLliam DAVIDSON INSTITUTE

AT THE UNIVERSITY OF MICHIGAN BUSINESS SCHOOL

\title{
Equilibrium Exchange Rates in Central and Eastern Europe: A Meta-Regression Analysis
}

\author{
By: Balázs Égert and László Halpern
}

William Davidson Institute Working Paper Number 769

May 2005 


\title{
Equilibrium Exchange Rates in Central and Eastern Europe: A Meta-Regression Analysis ${ }^{1}$
}

\author{
Balázs Égert* László Halpern*
}

\begin{abstract}
This paper analyses the ever-growing literature on equilibrium exchange rates in the new EU member states of Central and Eastern Europe in a quantitative manner using meta-regression analysis. The results indicate that the real misalignments reported in the literature are systematically influenced, inter alia, by the underlying theoretical concepts (Balassa-Samuelson effect, Behavioural Equilibrium Exchange Rate, Fundamental Equilibrium Exchange Rate) and by the econometric estimation methods. The important implication of these findings is that a systematic analysis is needed in terms of both alternative economic and econometric specifications to assess equilibrium exchange rates.
\end{abstract}

JEL: C15, E31, F31, O11, P17.

Keywords: equilibrium exchange rate, Balassa-Samuelson effect, meta-analysis

\footnotetext{
"Oesterreichische Nationalbank, University of Paris X-Nanterre and William Davidson Institute. E-mail: balazs.egert@oenb.at and begert@u-paris10.fr

- Institute of Economics of Hungarian Academy of Sciences, CEPR, William Davidson Institute and Central European University. E-mail: halpern@econ.core.hu

${ }^{1}$ The authors would like to thank Iikka Korhonen for helpful comments. We are especially grateful to Paul Wachtel and an anonymous referee, whose helpful comments and suggestions significantly improved the paper throughout several rounds of revisions. The paper benefited from comments of participants at the $10^{\text {th }}$ Dubrovnik Economic Conference and at a seminar held at BOFIT. Many thank goes to Irene Mühldorf for excellent language advice. Part of this work was carried out while Égert was visiting BOFIT in December 2004 and January 2005. The opinions expressed in the paper are those of the authors and do not necessarily represent the views of the Oesterreichische Nationalbank or the European System of Central Banks (ESCB).
} 


\section{Introduction}

Equilibrium exchange rates have consistently drawn the attention of both academic researchers and policy-makers in industrialised countries for the last decade (Cf. Williamson, 1994; MacDonald, 1995, 2000; Stein, 1995, 2002; and Driver and Westaway, 2004). This is all the more true for the new EU member states of Central and Eastern Europe, which started their transformation process from plan to market in the late 1980s and early 1990s (e.g. Halpern and Wyplosz, 1997; and Krajnyák and Zettelmeyer, 1998, for the early 1990s). A straightforward way to analyse the increasing literature on equilibrium exchange rates in Central and Eastern Europe is to have recourse to conventional literature surveys (Égert, Halpern and MacDonald, 2004). However, traditional literature surveys may contain some degree of subjectivity, as pointed out in Stanley (2001) and Florax, de Groot and de Mooij (2002). By contrast, a metaregression analysis of the literature may provide a less narrative and more statistical interpretation of the existing body of the literature in that it pins down structural characteristics and methodological features of the studies, which cause the estimation results of the individual papers to differ. Although meta-regression analysis has long been used quite extensively in some areas of economics, only few studies concentrate on macroeconomic issues. ${ }^{2}$ Even fewer studies deal with transition economics ${ }^{3}$ and especially exchange rate economics. For the latter area, our paper is, to our knowledge, the first meta-regression study.

Applying the meta-regression approach to the eight new EU member states of Central and Eastern Europe ${ }^{4}$, we ask a set of questions that are highly relevant for both academic research and policy-making. The questions that we raise are related to the size and the sign of the estimated real misalignments. In particular, the issues to be answered are whether the estimated real misalignment figures depend on the theoretical background and whether the use of time series, cross-sectional, or panel data, and applying different econometric estimation techniques can systematically influence the estimation results.

\footnotetext{
${ }^{2}$ Stanley (1998) studies the Ricardian equivalence. Knell and Stix $(2003,2004)$ analyse the robustness of money demand function estimates. Rose (2004) applies meta-analysis to study the trade creation effect of monetary unions. ${ }^{3}$ Djankov and Murrell (2002) analyse enterprise restructuring in transition economies in a quantitative way. Nonetheless, they do not perform proper meta-regression analysis. Fidrmuc and Korhonen (2004) perform metaregression to analyse the literature regarding the business cycle correlation between countries in Central and Eastern Europe and the euro area.

${ }^{4}$ The Czech Republic, Estonia, Hungary, Latvia, Lithuania, Poland, Slovakia and Slovenia.
} 
The remainder of the paper is structured in the following way. Section 2 describes the concept of meta-regression analysis. Section 3 presents the results and Section 4 concludes.

\section{The Concept of Meta-Regression Analysis}

Meta-analysis has a long tradition in medicine, especially in clinical medical trials, where it is used because medical experiments are costly, usually take long time and are typically conducted on small groups of individuals. The results of such individual trials all over the world can then be pooled together and analysed as a whole using statistical methods. Stanley (2001) cites the example of streptokinase, for which independent trials provided no conclusive evidence on whether it diminishes the risk of heart attack. Nonetheless, several meta-analyses came to the conclusion that it does have a beneficial effect on the heart.

Meta-analysis helped researcher to clarify controversial issues not only in medicine but also in economics, where it has gained more popularity since the 1980s (see e.g. Stanley and Jarrell, 1989, for an early overview of meta-analysis). Labour economics, industrial organisation, health economics and transportation economics are typical examples of areas where meta-analysis has been used extensively since the late 1980 s.

According to Weichselbaumer and Winter-Ebmer (2003), "a meta-study (...) allows a quantitative assessment of the literature in a way an econometrician would write a survey". It allows to formulate and subsequently to test hypotheses related to, for example, the size or the sign of a given coefficient estimate. Stanley (2001) claims that "meta-regression analysis can (...) offer specific reasons, based on the studies themselves, why the evidence on a certain question may appear contradictory or overly varied. Such studies can also suggest potentially fruitful lines for future inquiry (...)."

Meta-regression analysis, a type of meta-analysis, typically involves three stages: First, collect all relevant studies. Second, identify the dependent and independent variables and code them.

The study-to-study variation of the dependent variable is to be explained by the independent variables, which are structural characteristics and methodological features of the individual studies. The dependent variable contains usually a summary measure, such as the size of the real misalignment in our case or a coefficient estimate, whereas the independent variables are typically dummy variables. Third, regress the dependent variable on the set of independent 
variables. Stanley (2001) puts forward that "meta-regression analysis can identify the extent to which the particular choice of methods, design and data affect reported results."

\section{The Meta-Regression Analysis}

\section{A. Setting up the Experiments}

\section{The Studies}

As suggested above, the first two steps of a meta-regression analysis are the identification of the relevant papers and the appropriate coding of the variables. Our dataset includes 32 papers, mostly drawn from Égert, Halpern and MacDonald (2004) and completed with several other studies that became available by early 2004. Only papers which analyse the eight new EU member states of Central and Eastern Europe, namely the Czech Republic, Estonia, Hungary, Latvia, Lithuania, Poland, Slovakia and Slovenia, and which investigate the macroeconomic definition of the real exchange rate are considered here. The real exchange rate is defined as foreign relative to domestic price levels $\left(Q=E \cdot P^{*} / P\right)$, where $E$ is the nominal exchange rate expressed as units of domestic currencies in one unit of the foreign currency (a decrease/increase is an appreciation/depreciation) and $\mathrm{P}$ and $\mathrm{P}^{*}$ are the domestic and foreign price levels.

Florax, de Groot and de Mooij (2002) point out that a common problem with studies using metaanalysis is the construction of a representative sample of the literature. Our paper is not confronted with this problem:_ we use the whole sample of papers from the mid-1990s to early 2004 rather than a representative sample of the literature. Appendix Table A1 lists the papers used in this study with their main features.

\section{The Dependent Variable}

The dependent variable is the size of the real misalignment, i.e. the difference between the estimated equilibrium exchange rate and the observed real exchange rate. If a misalignment range is given in a study, the mean of the band is taken as the size of the real misalignment. The surveyed 32 studies provide us with a total of 170 observations for real misalignments from 1990 to 2002. If a paper provides more than one observation, i.e. observations for several countries, or an observation for a given country derived on the basis of different methods, then all these observations are collected. Stanley and Jarrell (1998) use only one observation per study. 
Weichselbaumer and Winter-Ebmer (2003) argue that this may involve a large degree of discretion and advocate including all observations available in a given study.

Table 1 below indicates that more than half of the observations, i.e. 88 observations, are from 2001 and 2002. It is reasonable to think that real misalignments obtained for two consecutive years are more comparable than those for the whole sample. For this reason, a sub-sample comprising data only for 2001 and 2002 is employed for the estimations beside the whole sample including misalignments from 1990 to 2002. Table 1 also shows the relative country coverage of our dataset. Of the eight countries analysed, the Czech Republic, Hungary, Poland, Slovenia, Estonia and Latvia are fairly evenly represented both in the whole sample and in the sub-sample. By contrast, Lithuania and Slovakia appear to be somewhat underrepresented. The reported real misalignments range from $-79 \%$ (undervaluation) to $40 \%$ (overvaluation) for the whole sample and from $-29 \%$ to $30 \%$ for the sub-sample. Most of the reported real misalignments are overvaluations ( $45 \%$ for the whole sample and $64 \%$ for the sub-sample), as depicted in Figure 1. The large negative figures for the full sample reflect the estimated initial undervaluations. The country-specific kernel density estimates reveal a great deal of heterogeneity across the countries. For the more recent period of 2001 to 2002, most of the countries had overvalued currencies, either in effective terms or vis-à-vis the euro area (or a benchmark proxy), perhaps with the exception of Latvia. Nevertheless, not only the size of the maximum overvaluation but also the mean and the shape of the kernel density estimations vary across the six countries under study. 
Table 1. Summary Statistics of Real Misalignments

\begin{tabular}{|lcclcc|}
\hline & 1990_2002 & $\mathbf{2 0 0 1} \mathbf{2 0 0 2}$ & & 1990_2002 & 2001_2002 \\
N. of Obs & 170 & 88 & CZ & $15.88 \%$ & $18.18 \%$ \\
MEAN & -4.64 & 4.16 & HU & $18.24 \%$ & $19.32 \%$ \\
MEDIAN & 0.00 & 3.75 & PL & $16.47 \%$ & $18.18 \%$ \\
MAX & 40.70 & 30.00 & SK & $8.82 \%$ & $2.27 \%$ \\
MIN & -79.00 & -29.00 & SI & $10.59 \%$ & $10.23 \%$ \\
STD. DEV. & 19.86 & 9.21 & EE & $14.71 \%$ & $14.77 \%$ \\
OVERVALUED & $44.71 \%$ & $63.64 \%$ & LV & $10.00 \%$ & $12.50 \%$ \\
UNDERVALUED & $35.29 \%$ & $18.18 \%$ & LT & $5.29 \%$ & $4.55 \%$ \\
FAIRLY VALUED & $20.00 \%$ & $18.18 \%$ & Total & $\mathbf{1 0 0 . 0 0 \%}$ & $\mathbf{1 0 0 . 0 0 \%}$ \\
TOTAL & $\mathbf{1 0 0 . 0 0 \%}$ & $\mathbf{1 0 0 . 0 0 \%}$ & & & \\
\hline
\end{tabular}

Note: $1990 \_2002$ refers to the whole sample and 2001_2002 stands for the sub-sample. MIS1990 to MIS2002 show the share of the respective years in the sample. CZ, HU, PL, SK, SI, EE, LV and LT denote the Czech Republic, Hungary, Poland, Slovakia, Slovenia, Estonia, Latvia and Lithuania, respectively.

Figure 1. Distribution of Real Misalignments
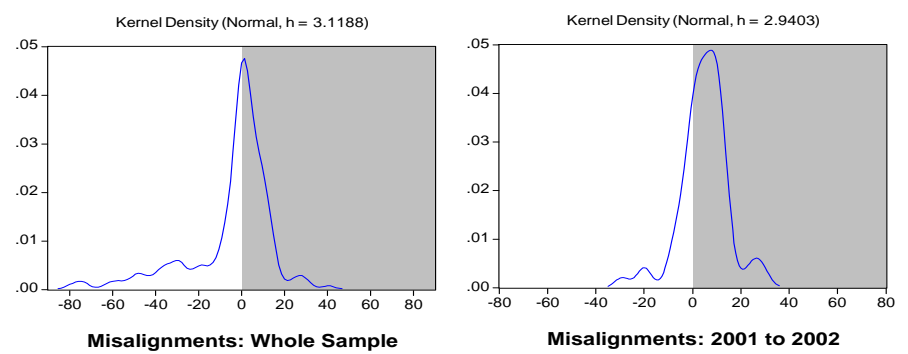

\section{Explanatory Variables}

The explanatory variables are dummy variables, i.e. they take the value of either 0 or 1 . An important group of explanatory variables concerns the theoretical background of the studies. The theoretical backgrounds employed are the Balassa-Samuelson effect (BS), the Behavioural Equilibrium Exchange Rate (BEER), the Permanent Equilibrium Exchange Rate (PEER), the Fundamental Equilibrium Exchange Rate (FEER), and the Fundamental Real Exchange Rate (FRER), i.e. the foreign debt-augmented variant of FEER. Although its theoretical background is the risk premium-augmented uncovered interest parity, the BEER approach can be thought of as a statistical approach which aims to link the real exchange rate to a set of economic fundamentals. The equilibrium exchange rate is obtained by plugging in the long-term values of the fundamentals into the estimated equations, and the real misalignment is obtained as the difference between the observed real exchange rate and the estimated "equilibrium" real exchange rate. PEER differs from BEER in that it decomposes directly the estimated long-term cointegration relationship into transitory and permanent components, with the latter constituting 
the measure of the equilibrium exchange rate. FEER is a macro model-based approach, in which the equilibrium exchange rate is given by the real exchange rate, which causes the current account to move to its long-term sustainable target, conditioned on the simultaneous attainment of the internal balance usually defined in terms of the nonaccelerating inflation rate of unemployment (NAIRU). FRER differs from FEER in that it also stipulates a foreign debt target to be obtained in the long run.

Given that only two observations are at hand for the NATREX model and the Macroeconomic Balance approach, we decided to ignore them. The single-equation estimate for the NATREX reported in Karádi (2003) is classified as BEER.

As shown in Table 2, BEER is the most commonly used approach with a share of over 50\% in the sample. The share of the other approaches differs across the two samples. In the full sample, the BS has a share of $28 \%$, followed by PEER and FEER with about $10 \%$ each. In the subsample, the second most frequently used approaches are PEER and FEER with a share of about $20 \%$ each, while BS ranks at the end with $6 \%$.

Table 2. Theoretical Background for Real Misalignments

\begin{tabular}{|lrr|}
\hline & 1990_2002 & 2001_2002 \\
BS & $28.24 \%$ & $5.68 \%$ \\
BEER & $52.35 \%$ & $56.82 \%$ \\
PEER & $10.59 \%$ & $20.45 \%$ \\
MACROMODEL & $8.82 \%$ & $17.05 \%$ \\
Of which & & \\
FEER & $3.53 \%$ & $6.82 \%$ \\
FRER & $5.29 \%$ & $10.23 \%$ \\
\hline
\end{tabular}

In addition to the aforesaid dummies, a score of other, more general variables are also introduced and applied to all specifications. First, a group of explanatory variables are used to capture differences of the econometric estimation techniques (different time series and panel techniques). Second, a class of dummy variables is employed to analyse whether the use of time series, insample and out-of-sample estimates and cross-sectional data do matter. A third group of control variables is concerned with the construction of the real exchange rate, i.e. whether it is based on the real effective exchange rate, the real exchange rate vis-à-vis the euro area (or a proxy like Germany or Austria) or the USA, or whether it is based on the CPI, the PPI or real dollar wages. Also, a set of dummy variables is used to control for publication bias, that is, whether published papers produce systematically higher or lower estimates than those obtained in unpublished 
papers. To capture year-specific and country-specific misalignments, time and country dummies are used. A detailed definition of the variables is provided in Appendix Table A2.

\section{B. Estimation Results}

\section{Real misalignments}

There are two important issues we seek to investigate here. The first one relates to whether the underlying theoretical approaches, i.e. the Balassa-Samuelson effect, BEER, PEER, FEER and FRER have a systematic impact on the size of the real misalignment. Égert, Halpern and MacDonald (2004) provide the time hierarchy of the different theories and argue that although the different approaches are connected with each other, they apply at different time horizons. The estimation results reported in Table 4 lend support to this hypothesis. Comparing the different approaches with the BEER approach ${ }^{5}$, it turns out that FEER is significantly different for the whole sample. Regarding the sub-sample, in addition to FEER, PEER also becomes significantly different from BEER. It should be noted that these results are based on the adjusted samples. ${ }^{6}$ For the unadjusted data sample, the FRER approach appears to provided different results. A reason why FRER becomes insignificant in the adjusted sample is that its higher values fall in the trimmed upper or lower three percentiles. In general, FEER, FRER and PEER yield higher misalignment figures than BEER.

The second issue we examine is the time hierarchy of the real misalignment estimates. BEER and PEER estimations rest on a single equation which connects the real exchange rate and the fundamentals. Such a specification can be estimated using (a) time series, (b) panel data, and (c) cross-sectional data. If there is a long-term cointegration relationship between the real exchange rate and the fundamentals, real misalignments derived from (a) time series estimates should show a short- and medium-term deviation from the long-term relationship. When using (b) panel data, the estimated deviation of the equilibrium exchange rate from the observed exchange rate may be larger because panel data may be construed as referring to longer time horizons. The use of in-

\footnotetext{
${ }^{5}$ It is always convenient to code the alternative approaches relative to the one with most of the observations. BEER has a relative share of about $50 \%$.

${ }^{6}$ When investigating the determinants of the real misalignments, two equations are estimated. The first one is based on the full sample, whereas the second one is adjusted for possible outliers by trimming the upper and lower three percentiles of the sample. It should also be noted that year-specific and country-specific dummies are always included in the estimated equations.
} 
sample panel data implies that the estimated coefficients reflect some kind of average for a group of transition economies. Thus, the computed real misalignment should be viewed as a mediumto long-term deviation. Out-of-sample data ${ }^{7}$ may include either a group of developed countries (e.g. Kim and Korhonen, 2002; Maeso-Fernandez, Osbat and Schnatz, 2004; and Égert, Lahrèche-Révil and Lommatzsch, 2004) or possibly all (market) economies in the world (e.g. Halpern and Wyplosz,1997; and Krajnyák and Zettelmeyer, 1998). Using out-of-sample data including developing countries implies that the equilibrium exchange rate of transition economies behaves like that in developed countries (with which transition economies are making an effort to catch up in the long term), whereas employing out-of-sample data composed exclusively of industrialised economies rests on the assumption that all market economies behave similarly in the (very) long run, as do equilibrium exchange rates. Either way, real misalignments derived from out-of-sample estimates reflect (very) long-run misalignments. Finally, cross-section estimates usually relate the real exchange rate to the dual productivity differential. In such a setting, all variables are expressed in levels rather than the indices commonly used in other BEER estimations. An exception is the paper by Maeso-Fernandez, Osbat and Schnatz (2004), who use level data in a panel setting. Such a bivariate setting is capable of answering the question of how far the real exchange rate is situated from the real exchange rate that would be given by relative productivity levels. Thus, misalignments obtained on the basis of cross-sectional data can be viewed as medium- to long-term misalignments.

Table 3 shows that for the whole sample, the unadjusted data indicate that real misalignments derived on the basis of cross-section and out-of-sample estimations result in higher misalignments than time series estimations. When adjusting for outliers, in-sample estimations appear to yield significantly lower real misalignments than estimations based on time series. The results obtained for the sub-sample 2001 and 2002 should be taken with a grain of salt, because the share of cross-sectional and panel observations is rather limited there. Yet we can find some evidence that in-sample panel estimations provide significantly lower real misalignments than time series estimations. Table 3 also indicates that the country dummies enter the estimated equations significantly. Given that Hungary is taken as a benchmark, these results suggest that real misalignments in Hungary are systematically different from those of the other countries.

\footnotetext{
${ }^{7}$ The expression out-of-sample refers to the fact that the CEECs for which real misalignments are computed are not included in the dataset.
} 
More specifically, the real misalignment figures reported in the literature are systematically higher in Hungary than in all other countries except Poland. These results imply, perhaps unsurprisingly, that estimated real misalignments vary across countries.

Table 3. Estimation Results for the Real Misalignments

\begin{tabular}{|c|c|c|c|c|c|c|c|c|}
\hline \multicolumn{9}{|c|}{ Dependent variable: Real misalignment } \\
\hline \multirow{3}{*}{$\begin{array}{l}\text { Explanatory } \\
\text { Variables }\end{array}$} & \multicolumn{4}{|c|}{$1990-2002$} & \multicolumn{4}{|c|}{$2001-2002$} \\
\hline & \multicolumn{2}{|l|}{ Eq1 } & \multicolumn{2}{|l|}{ Eq2 } & \multicolumn{2}{|l|}{ Eq1 } & \multicolumn{2}{|l|}{ Eq2 } \\
\hline & Full & Adj & Full & Adj & Full & Adj & Full & Adj \\
\hline $\mathrm{C}$ & $10.741 * * *$ & $4.836^{* *}$ & $10.141 * * *$ & $6.342 * * *$ & $7.783 * * *$ & $4.584 * * *$ & $5.307 * *$ & $5.404 * * *$ \\
\hline \multicolumn{9}{|c|}{ Theoretical background } \\
\hline $\mathrm{BS}$ & 2.983 & 1.941 & & & 2.812 & 0.026 & & \\
\hline PEER & 1.038 & 0.692 & & & 2.213 & $3.981 * * *$ & -1.707 & -1.305 \\
\hline FEER & 7.891 & $10.203 * *$ & $12.361 *$ & $10.089 * *$ & 9.794 & $7.643 *$ & $7.428 * *$ & 0.776 \\
\hline FRER & 5.327 & 1.130 & 4.048 & 0.420 & $7.136^{* *}$ & 3.210 & & \\
\hline \multicolumn{9}{|c|}{ Time series and cross-sectional dimension } \\
\hline CROSS & & & $14.125^{* *}$ & 0.962 & & & 1.772 & 0.472 \\
\hline INSMPL & & & -0.025 & $-9.632 * *$ & & & 3.297 & $-5.925 *$ \\
\hline OUTSMPL & & & $19.118 * *$ & -0.527 & & & & \\
\hline \multicolumn{9}{|c|}{ Construction of the real exchange rate } \\
\hline REER & -2.262 & -0.600 & -0.292 & -1.293 & -2.204 & -2.041 & & \\
\hline RER_USD & -2.030 & -0.204 & $-11.019 *$ & -0.433 & -5.686 & -0.155 & & \\
\hline RER_PPI & $-8.336^{*}$ & $-7.719 * *$ & -7.017 & $-8.322 * *$ & $-8.784 * *$ & $-4.035^{*}$ & & \\
\hline RER_W & $-20.030 * * *$ & $-10.164 *$ & $-18.463 * * *$ & -8.253 & & & & \\
\hline \multicolumn{9}{|c|}{ Publication bias } \\
\hline PUBLI_NAT & $-15.554 * * *$ & $-11.934 * * *$ & $-19.382 * * *$ & $-11.736 * * *$ & -12.596 & -7.020 & & \\
\hline PUBLI_INT & -7.270 & 3.127 & -1.738 & 4.464 & 1.353 & 4.952 & & \\
\hline PUBLI_NO & -5.338 & -3.576 & $-5.965^{*}$ & -3.877 & $-5.373 * *$ & -0.185 & & \\
\hline \multicolumn{9}{|c|}{ Country dummies } \\
\hline $\mathrm{CZ}$ & $-5.885^{*}$ & -3.578 & $-6.005 * *$ & $-4.210 *$ & 0.197 & 1.641 & -0.279 & 0.763 \\
\hline PL & 1.650 & 2.808 & 1.687 & 2.844 & 1.516 & $4.144 * *$ & 1.382 & $3.540 * *$ \\
\hline SK & $-7.050 *$ & $-4.956^{*}$ & $-6.748^{*}$ & $-5.102 *$ & $10.708 *$ & 4.806 & 10.828 & 6.041 \\
\hline SI & -3.021 & -0.278 & -3.348 & -0.241 & $-6.423 * *$ & -2.223 & -5.452 & -2.324 \\
\hline $\mathrm{EE}$ & $-5.738^{*}$ & 0.093 & $-5.745^{*}$ & -0.083 & -1.018 & -0.383 & -1.911 & -1.844 \\
\hline LV & $-9.938 * *$ & -2.594 & $-8.895 * *$ & -2.739 & -4.559 & -0.388 & $-10.159 * * *$ & $-4.754 * *$ \\
\hline LT & $-12.483^{* *}$ & -3.800 & $-11.628 * *$ & -3.661 & $-8.756^{*}$ & -5.688 & $-10.466^{* *}$ & $-6.695^{*}$ \\
\hline No: Obs & 170 & 139 & 170 & 139 & 88 & 69 & 88 & 69 \\
\hline $\mathrm{R} 2$ & 0.716 & 0.622 & 0.728 & 0.638 & 0.511 & 0.524 & 0.322 & 0.405 \\
\hline R2 Adj & 0.662 & 0.531 & 0.674 & 0.545 & 0.384 & 0.353 & 0.213 & 0.277 \\
\hline
\end{tabular}

Note: *** and *** indicate that the variable is significant at the $10 \%, 5 \%$ and $1 \%$ level, respectively. "Full" refers to the raw sample while "adj" is the sample adjusted for possible outliers by trimming the upper and lower three percentiles. Year-specific and country-specific dummies are always included in the equations.

\section{Econometric estimation methods}

Some evidence can be found that the econometric estimation methods can influence the size of the derived real misalignment (see Table 4). The Engle-Granger method is used as a common denominator in all equations. There is at least one alternative econometric technique for all 
reported equations that produces significantly different coefficient estimates. For the full sample, it appears that the pooled and the random effect panel OLS estimators cause systematically different estimates. The result for random effect panel OLS estimators should be treated with caution. The econometric methods are not tested for jointly with other characteristics of the studies because the econometric characteristics sometimes overlap with other characteristics. Most importantly, large panels for the early and mid-1990s are usually estimated using random effect OLS. Hence, the large initial undervaluation detected in these studies may also show up here as a result of different econometric techniques. For the sub-period of 2001-2002, these studies are not included and there are no overlaps between different characteristics. Table 4 reports that it is mostly the Johansen cointegration technique that yields statistically different misalignment estimations. Note that the results do not change if the Johansen technique is taken as a common denominator for the estimations.

Table 4. Econometric Techniques

\begin{tabular}{l|l|l|l|l|}
\multicolumn{5}{|c|}{ Dependent variable } \\
\hline & \multicolumn{3}{|c|}{ Real misalignment } \\
\hline & \multicolumn{3}{|c|}{ Eq 1 $1990-2002$} & \multicolumn{2}{c|}{ Eq 2001-2002 } \\
\hline Expl. Var. & Full & Adj & Full & Adj \\
\hline C & 4.262 & 0.539 & 0.251 & 1.471 \\
\hline FMOLS & & & & \\
DOLS & 3.890 & 7.158 & 5.230 & 3.807 \\
ARDL & 3.404 & 5.749 & 4.744 & 3.320 \\
JOHANSEN & 3.106 & 2.191 & $4.862^{*}$ & $4.60 * * *$ \\
POLS & -10.711 & $-12.882^{* *}$ & 3.049 & -0.912 \\
FE_OLS & -8.077 & -7.737 & & \\
RE_OLS & $-45.393 * * *$ & $-27.378^{* * *}$ & & \\
GLS & -7.629 & -10.400 & & \\
PFMOLS & & & & \\
PDOLS & 8.182 & -2.945 & 7.646 & -1.521 \\
PMGE & 0.859 & -4.947 & & \\
MGE & & & & 0.441 \\
\hline No. Obs & 155 & 121 & 73 & 0.260 \\
R2 & 0.708 & 0.475 & 0.320 & \\
R2 Adj & 0.648 & 0.330 & 0.170 & \\
Note: as for Table 4 & & &
\end{tabular}

\section{Conclusion}

Using meta-regression analysis, we found important structural differences for the estimated real misalignment obtained for the eight new EU member states from Central and Eastern Europe. We showed that the underlying theoretical background mattered for real misalignment estimates. 
BEER, PEER and FEER estimates are found to yield significantly different real misalignment estimates. Also, it turned out that the use of time series and in-sample and out-of-sample panels may cause the size of an over- or undervaluation to differ. These findings may be due to the fact that these approaches apply at different time horizons.

Our results have important implications. If one seeks to assess the equilibrium exchange rate of any given economy, a systematic analysis using alternative economic and econometric specifications must be performed because different approaches and techniques turn out to yield systematically different results. In addition, when interpreting the range of the derived real misalignments, the connection between the alternative theoretical and empirical approaches should be carefully analysed.

\section{References}

Alberola, E., 2003. Real Convergence, External Disequilibria and Equilibrium Exchange Rates in EU Acceding Countries. Banco de España, mimeo.

Alonso-Gamo, P., S. Fabrizio, V. Kramarenko and Q. Wang, 2002. Lithuania: History and Future of the Currency Board Arrangement. IMF Working Paper No. 127.

Avallone, N. and A. Lahrèche-Révil, 1999. Le taux de change réel d'équilibre dans les pays en transition: le cas de la Hongrie, TEAM, University of Paris I - Sorbonne, Cahiers blancs no. 91.

Begg, D., Halpern, L. and Ch. Wyplosz, 1999. Monetary and Exchange Rate Policies, EMU and Central and Eastern Europe. Forum Report on the Economic Policy Initiative No. 5. London: CEPR and New York, Prague: EastWest Institute.

Beguna, A., 2002. Competitiveness and the Equilibrium Exchange Rate in Latvia. EuroFaculty Working Paper in Economics No. 16, Riga: University of Latvia and EuroFaculty.

Bitans, M., 2002. Real Exchange Rate in Latvia: 1994-2001. Bank of Latvia Working Paper.

Bitans, M. and I. Tillers, 2003. Estimates of Equilibrium Exchange Rate in Latvia. Bank of Latvia, mimeo.

Braumann, B., 1998. Republic of Slovakia: Recent Economic Developments. IMF Staff Country Report No. 60, 35-47.

Burgess, R., Fabrizio, S. and Y. Xiao, 2003. Competitiveness in the Baltics in the Run-Up to EU Accession. IMF Country Report No. 114.

Čihák, M and T. Holub, 2003. Price Convergence to the EU: What Do the 1999 ICP Data Tell Us? Czech National Bank Working Paper Series No. 2.

Čihák, M. and T. Holub, 2001. Convergence of Relative Prices and Inflation in Central and Eastern Europe, IMF Working Paper No. 124.

Coudert, V., 1999. Comment définir un taux de change d'équilibre pour les pays émergents? Economie Internationale, $77,1^{\text {er }}$ trimestre, 45--65.

Coudert, V. and C. Couharde, 2002. Exchange Rate Regimes and Sustainable Parities for CEECs in the Run-up to EMU Membership, CEPII Working Paper No. 15.

Csajbók, A. and M. A. Kovács, 2002. FEER Enough? National Bank of Hungary, mimeo. 
De Broeck, M. and T. Sløk, 2001. Interpreting Real Exchange Rate Movements in Transition Countries, IMF Working Paper No. 56.

Djankov, S. and P. Murrell, 2002. Enterprise Restructuring in Transition: A Quantitative Survey, Journal of Economic Literature, 40(3), 739--792.

Driver, R. L. and P. F. Westaway, 2004. Concepts of Equilibrium Real Exchange Rates. Bank of England Working Paper No. 248.

Égert, B. and A. Lahrèche-Révil, 2003. Estimating the Equilibrium Exchange Rate of the Central and Eastern European Acceding Countries: The Challenge of Euro Adoption. Weltwirtschaftliches Archiv, 139(4), 683--708.

Égert, B. and K. Lommatzsch, 2003. Equilibrium Exchange Rates in Acceding Countries: How Large Is Our Confidence (Interval)? Oesterreichische Nationalbank. Focus on Transition No. 2., 107--37.

Égert B., Halpern, L. and R. MacDonald, 2004. Equilibrium Exchange Rates in Transition Economies: Taking Stock of the Issues, CEPR Discussion Paper No 4809.

Égert, B., A. Lahrèche-Révil and K. Lommatzsch, 2004. The Stock-Flow Approach to the Real Exchange Rate of CEE Transition Economies, CEPII Working Paper No.14.

Fidrmuc, J. and I. Korhonen, 2004. Meta-Analysis of the Business Cycle Correlation Between the Euro Area and the CEECs: What Do We Know? And Who Cares? BOFIT Discussion Paper No. 20.

Filipozzi, F., 2000. Equilibrium Exchange Rate of the Estonian Kroon, Its Dynamics and Its Impacts of Deviations. Bank of Estonia Working Paper No. 3.

Florax, R., H. de Groot and R. de Mooij, 2002. Meta-Analysis. Tingergen Institute Discussion Paper No 41/3.

Halpern, L. and Ch. Wyplosz, 1997. Equilibrium Exchange Rates in Transition Countries. IMF Staff Papers 44(4), 430--461.

Hinnosar, M., R. Juks, H. Kaadu and L. Uusküla, 2003. Estimating the Equilibrium Exchange Rate of the Estonian Kroon. Bank of Estonia, mimeo

Karádi, P. 2003. Structural and Single Equation Estimation of the NATREX Equilibrium Real Exchange Rate of the Hungarian Forint. National Bank of Hungary, mimeo.

Kazaks, M., 2000. Real exchange rate appreciation and loss of competitiveness. The case of Latvia. Presented at the Second Seminar of Managing Economic Transition in Eastern Europe, May 24, 2000, University College London, School of Slavonic and East European Studies.

Kim, B. Y. and I. Korhonen, 2002. Equilibrium Exchange Rates in Transition Countries: Evidence from Dynamic Heterogeneous Panel Models. BOFIT Discussion Paper No. 15.

Knell, M. and H. Stix, 2003. How Robust Are Money Demand Estimations? A Meta-Analytical Approach. Oesterreichische Nationalbank Working Paper No. 81.

Knell, M. and H. Stix, 2004. Three Decades of Money Demand Studies. Some Differences and Remarkable Similarities. Oesterreichische Nationalbank Working Paper No. 88.

Krajnyák, K. and J. Zettelmeyer, 1998. Competitiveness in Transition Economies: What Scope for Real Appreciation? IMF Staff Papers, 45, 309--362.

Lommatzsch, K. and S. Tober (2002) What Is behind the Real Appreciation of the Accession Countries' Currencies? An Investigation of the PPI-Based Real Exchange Rate, presented at "Exchange Rate Strategies during the EU Enlargement." Budapest. 27 - 30 November.

MacDonald, R., 1995. Long-run Exchange Rate Modeling: A Survey of the Recent Literature. IMF Staff Papers, 42(3), 437--489.

MacDonald, R., 2000. Concepts to Calculate Equilibrium Exchange Rates: An Overview, Deutsche Bundesbank Discussion Paper No 3. 
Maeso-Fernandez, F., Ch. Osbat and B. Schnatz, 2004. Towards the Estimation of Equilibrium Exchange Rates for CEE Acceding Countries: Methodological Issues and a Panel Cointegration Perspective. European Central Bank Working Paper No. 353.

Rahn, J., 2003. Bilateral Equilibrium Exchange Rates of the EU Accession Countries Against the Euro. BOFIT Discussion Paper No. 11.

Randveer, M. and M. Rell., 2002. The Relationship Between Competitiveness and Real Exchange Rate in Estonia. Bank of Estonia Research Paper.

Rawdanowicz, Ł. W., 2003. Poland's Accession to EMU: Choosing the Exchange Rate Parity. Forthcoming in: De Souza, L.V. and B. Van Aarle (Eds.), The Euro Area and the New EU Member States. New York: Palgrave Macmillan.

Rose, A.K., 2004. A Meta-Analysis of the Effect of Common Currencies on International Trade. NBER Working Paper No. 10373.

Šmídková, K. and A. Bulir, 2005. Would Fast Sailing Towards the Euro Be Smooth? What Fundamental Real Exchange Rates Tell Us About Acceding Countries. IMF Working Paper.

Šmídková, K., R. Barrell and D. Holland, 2002. Estimates of Fundamental Real Exchange Rates for the Five EU Pre-Accession Countries. Czech National Bank Working Paper Series No. 3.

Stanely, T.D., 1998. New Wine in Old Bottles: A Meta-Analysis of Ricaridan Equivalence, Southern Economic Journal, 64, 713--27.

Stanley, T.D., 2001. Wheat from Chaff: Meta-Analysis as Quantitative Literature Review. Journal of Economic Perspectives, 15(3), 131--150.

Stanley, T.D. and S. B. Jarrell, 1989. Meta-Regression Analysis: A Quantitative Method of Literature Surveys, Journal of Economics Surveys, 3, 54--67.

Stanley, T.D. and S. B. Jarrell, 1998. Gender Wage Discrimation Bias? A Meta-Regression Analysis, Journal of Human Sciences, 33(4), 947--973.

Stein, J. L., 1995. The Fundamental Determinants of the Real Exchange Rate of the U.S. Dollar Relative to Other G7 Countries, IMF Working Paper No. 81.

Stein, J. L., 2002. The Equilibrium Real Exchange Rate of the Euro: An Evaluation of Research. CESifo Economic Studies, Zeitschrift für empirische Wirtschaftsforschung, 43(3), 349--381.

Vetlov, I., 2002. Analysis of the Real Exchange Rate and Competitiveness in Lithuania, Bank of Estonia Research Paper.

Vonnák B. and G. Kiss, 2003. The Equilibrium Exchange Rate of the Forint: Using the BEER Methodology. National Bank of Hungary, mimeo.

Weichselbaumer, D. and R. Winter-Ebmer, 2003. A Meta-Analysis of the International Gender Wage Gap. University of Linz Working Paper No. 11.

Williamson, J., 1994. Estimates of FEERs, in: Williamson, J., (ed.), Estimating Equilibrium Exchange Rates, Washington D.C.: Institute for International Economics, 177--244. 


\section{Appendix}

Table A1. Overview of the Studies Analysed

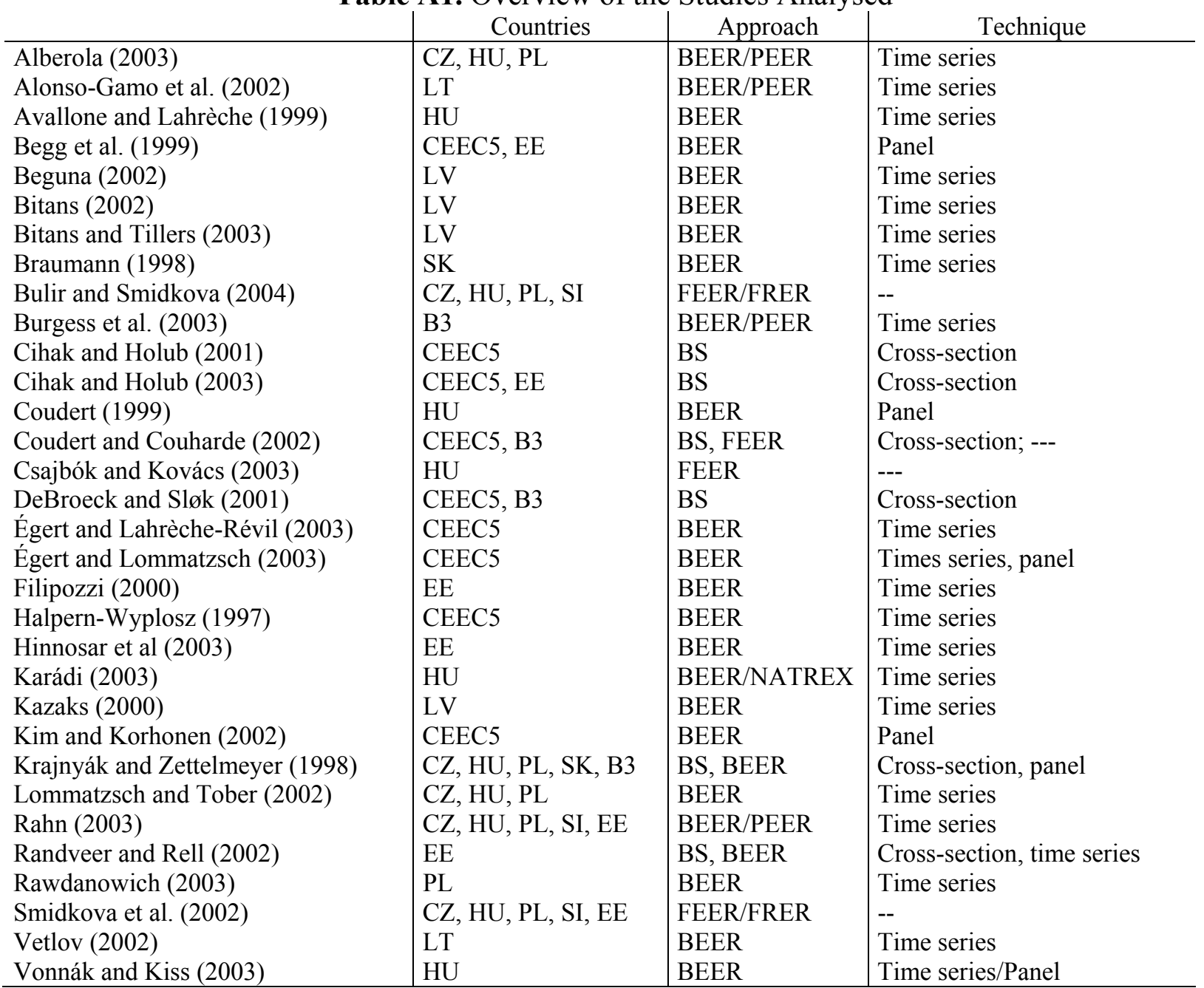

Note: BS, BEER, PEER, FEER, NATREX denote the theoretical approaches used in the papers. CEEC5 includes the Czech Republic, Hungary, Poland, Slovakia and Slovenia. B3 is the three Baltic states, i.e. Estonia, Latvia and Lithuania. CZ, HU, PL, SK, SI, EE, LV and LT stand for the Czech Republic, Hungary, Poland, Slovakia, Slovenia, Estonia, Latvia and Lithuania, respectively. 
Table A2. Codes of the Dependent and Explanatory Variables

DEPENDENT VARIABLE

MISALIGNMENT

$=$ the point estimate of the real misalignment

EXPLANATORY VARIABLES

Theoretical background
BS
BEER
MACROMODEL
FEER
FRER
Estimation methods
OLS_CR
EG
FMOLS
DOLS
ARDL
JOHANSEN
POLS
FE_OLS
RE_OLS
GLS
PFMOLS
PDOLS
PMGE
MGE

$=1$ if a study uses the Balassa-Samuelson framework

$=1$ if a study draws on the Behavourial Equilibrium Exchange Rate approach

$=1$ if a study uses a macromodel

$=1$ if a study draws in the Fundamental Equilibrium Exchange Rate approach

$=1$ if a study draws on the Fundamental Real Equilibrium Exchange Rate

$=1$ if a study uses OLS for cross sectional data

$=1$ if a study uses the Engle-Granger method

$=1$ if a study uses fully modified OLS

$=1$ if a study uses Dynamic OLS

$=1$ if a study uses Autoregressive Distributed Lags

$=1$ if a study uses the Maximum Likelihood estimator of Johansen

$=1$ if a study uses pooled OLS

$=1$ if a study uses fixed effect OLS

$=1$ if a study uses random effect OLS

$=1$ if a study uses generalised least squares

$=1$ if a study uses panel fully modified OLS

$=1$ if a study uses panel dynamic OLS

$=1$ if a study uses the pooled mean group estimator

$=1$ if a study uses the mean group estimator

\section{Time series and cross-sectional dimension}

TIMESERIES

PANEL

$=1$ if a study uses times series

IN_SMPL

OUT_SMPL

CROSSS

$=1$ if a study uses panel data

$=1$ if a study uses in-sample panel data

$=1$ if a study uses out-of-sample panel data

Real exchange rates

REER

RER_EURO

RER E

RER_DE

RER AT

RER_USD

RER_CPI

RER PPI

RER ${ }^{-} \mathrm{W}$

Publication record

PUBLI

PUBLI_INT

PUBLI_NAT

PUBLI_WP

PUBLI_NO

$=1$ if a study uses cross sectional data

$=1$ if a study uses real effective exchange rate

$=1$ if a study uses real exchange rate vis-à-vis a proxy of the euro area

$=1$ if a study uses real exchange rate vis-à-vis the euro area

$=1$ if a study uses real exchange rate vis-à-vis Germany

$=1$ if a study uses real exchange rate vis-à-vis Austria

$=1$ if a study uses real exchange rate vis-à-vis the US

$=1$ if a study uses CPI-deflated real exchange rate

$=1$ if a study uses PPI-deflated real exchange rate

$=1$ if a study uses dollar wage as a proxy for the real exchange rate

$=1$ if a study is published in a peer-reviewed journal

$=1$ if a study is published in an international peer-reviewed journal

$=1$ if a study is published in a non-English peer-reviewed journal

$=1$ if a study appeared as a working paper, is published in a book, conference volume or in a not refereed journal

$=1$ if a study is a mimeo or conference paper 


\section{DAVIDSON INSTITUTE WORKING PAPER SERIES - Most Recent Papers}

The entire Working Paper Series may be downloaded free of charge at: www.wdi.bus.umich.edu

CURRENT AS OF 5/05/05

\begin{tabular}{|c|c|c|}
\hline Publication & Authors & Date \\
\hline $\begin{array}{l}\text { No. 771: Non-Linear Exchange Rate Dynamics in Target Zones: A } \\
\text { Bumpy Road Towards A Honeymoon }\end{array}$ & $\begin{array}{l}\text { Jesús Crespo-Cuaresma, Balázs } \\
\text { Égert, and Ronald MacDonald }\end{array}$ & May 2005 \\
\hline $\begin{array}{l}\text { No. 770: Equilibrium Exchange Rates in Southeastern Europe, Russia, } \\
\text { Ukraine and Turkey: Healthy or (Dutch) Diseased? }\end{array}$ & Balázs Égert & May 2005 \\
\hline $\begin{array}{l}\text { No. 769: Equilibrium Exchange Rates in Central and Eastern Europe: A } \\
\text { Meta-Regression Analysis }\end{array}$ & Balázs Égert and László Halpern & May 2005 \\
\hline $\begin{array}{l}\text { No. 768: Testing for inflation convergence between the Euro Zone } \\
\text { and its CEE partners }\end{array}$ & Imed Drine and Christophe Rault & Apr. 2005 \\
\hline $\begin{array}{l}\text { No. 767: Labor Mobility during Transition: Evidence from the Czech } \\
\text { Republic }\end{array}$ & Jan Fidrmuc & Apr. 2005 \\
\hline $\begin{array}{l}\text { No. 766: Formation of social capital in Central and Eastern Europe: } \\
\text { Understanding the gap vis-à-vis developed countries }\end{array}$ & Jan Fidrmuc and Klarita Gërxhani & Apr. 2005 \\
\hline $\begin{array}{l}\text { No. 765: Do Regional Integration Agreements Increase Business-Cycle } \\
\text { Convergence? Evidence From APEC and NAFTA }\end{array}$ & $\begin{array}{l}\text { Viviana Fernandez and Ali M. } \\
\text { Kutan }\end{array}$ & Apr. 2005 \\
\hline $\begin{array}{l}\text { No. 764: State Regulations, Job Search and Wage Bargaining: A Study } \\
\text { in the Economics of the Informal Sector }\end{array}$ & Maxim Bouev & Apr. 2005 \\
\hline $\begin{array}{l}\text { No. 763: The Feldstein-Horioka Puzzle Revisited: An “European- } \\
\text { Regional” Perspective }\end{array}$ & $\begin{array}{l}\text { Jérôme Hericourt and Mathilde } \\
\text { Maurel }\end{array}$ & Apr. 2005 \\
\hline $\begin{array}{l}\text { No. 762: Transatlantic Differences in Labour Markets Changes in Wage } \\
\text { and Non-Employment Structures in the 1980s and the 1990s }\end{array}$ & Patrick A. Puhani & Mar. 2005 \\
\hline $\begin{array}{l}\text { No. 761: Resolution, Recovery and Survival: The Evolution of Payment } \\
\text { Disputes in Post-Socialist Europe }\end{array}$ & William Pyle & Mar. 2005 \\
\hline $\begin{array}{l}\text { No. 760: Official Foreign Exchange Interventions in the Czech } \\
\text { Republic: Did They Matter? }\end{array}$ & Balázs Égert and Luboš Komárek & Mar. 2005 \\
\hline $\begin{array}{l}\text { No. 759: Assessing Market Expectations on Exchange Rates and } \\
\text { Inflation: A Pilot Forecasting System for Bulgaria }\end{array}$ & $\begin{array}{l}\text { Michael Berlemann, Kalina } \\
\text { Dimitrova, \& Nikolay Nenovsky }\end{array}$ & Mar. 2005 \\
\hline No. 758: Attitudes and Performance: An Analysis of Russian Workers & $\begin{array}{l}\text { Susan J. Linz and Anastasia } \\
\text { Semykina }\end{array}$ & Mar. 2005 \\
\hline $\begin{array}{l}\text { No. 757: Barter, Credit, and Welfare: A theoretical inquiry into the } \\
\text { barter phenomenon in Russia }\end{array}$ & José Noguera and Susan J. Linz & Mar. 2005 \\
\hline $\begin{array}{l}\text { No. 756: Sorting, Selection, and Transformation of the Return to } \\
\text { College Education In China }\end{array}$ & $\begin{array}{l}\text { Belton M. Fleisher, Haizheng Li, } \\
\text { Shi Li, and Xiaojun Wang }\end{array}$ & Mar. 2005 \\
\hline $\begin{array}{l}\text { No. 755: Foreign Exchange Interventions in Emerging Europe: } \\
\text { Should We Give a Damn? The Case of Croatia and Turkey }\end{array}$ & Balázs Égert and Maroje Lang & Mar. 2005 \\
\hline $\begin{array}{l}\text { No. 754: Targeting Relative Inflation Forecast as Monetary Policy } \\
\text { Framework for Adopting Euro }\end{array}$ & Lucjan T. Orlowski & Feb. 2005 \\
\hline $\begin{array}{l}\text { No. 753: Internet Entrepreneurship: Networks and Performance of } \\
\text { Internet Ventures In China }\end{array}$ & Bat Batjargal & Feb. 2005 \\
\hline $\begin{array}{l}\text { No. 752: Network Triads: Transitivity, Referral and Venture Capital } \\
\text { Decisions in China and Russia }\end{array}$ & Bat Batjargal & Feb. 2005 \\
\hline $\begin{array}{l}\text { No. 751: Software Entrepreneurship: Knowledge Networks and } \\
\text { Performance Of Software Ventures In China and Russia }\end{array}$ & Bat Batjargal & Feb. 2005 \\
\hline $\begin{array}{l}\text { No. 750: Retained State Shareholding in Chinese PLCs: Does } \\
\text { Government Ownership Reduce Corporate Value? }\end{array}$ & Lihui Tian and Saul Estrin & Feb. 2005 \\
\hline No. 749: Financial Development and Technology & Solomon Tadesse & Feb. 2005 \\
\hline No. 748: Banking Fragility and Disclosure: International Evidence & Solomon Tadesse & Feb. 2005 \\
\hline $\begin{array}{l}\text { No. 747: Consolidation, Scale Economies and Technological Change in } \\
\text { Japanese Banking }\end{array}$ & Solomon Tadesse & Feb. 2005 \\
\hline $\begin{array}{l}\text { No. 746: Trade Creation and Diversion Effects of Europe’s Regional } \\
\text { Liberalization Agreements }\end{array}$ & Yener Kandogan & Feb. 2005 \\
\hline No. 745: Quality of Institutions, Credit Markets and Bankruptcy & Christa Hainz & Feb. 2005 \\
\hline $\begin{array}{l}\text { No. 744: How Transition Paths Differ: Enterprise Performance in } \mathrm{F} \\
\text { and China }\end{array}$ & Sumon Bhaumik and Saul Estrin & Jan. 2005 \\
\hline
\end{tabular}

